\title{
Advances in Industrial Biotechnology
}

\section{Implementing the Bioecon- omy in a Densely Populated and Industrialized Country}

\author{
Manfred Kircher ${ }^{1,2^{*}}$ \\ ${ }^{1}$ Advisory Board KADIB, Frankfurt, Germany \\ ${ }^{2}$ Advisory Board CLIB2021, Düsseldorf, Germany
}

\begin{abstract}
Reaching the goals of the Paris Climate Agreement requires the bioeconomy to be widely established by 2050 . The inherent change from fossil- to bio-based feedstock is fundamental, requiring large additional biomass capacities for industrial purposes especially in industrialized metropolitan regions. However, planetary boundaries set limits and even biomass comes with an ecological burden. The industrial use of biomass should therefore primarily focus on organic chemistry as this sector depends on carbon. Adding the feedstock demand of bio-based chemistry and some biofuel and bioenergy to the current biomass production capacities requires the expansion of the feedstock portfolio beyond primary biomass and the improvement of feedstock efficiency. Municipal and industrial residuals and waste materials are available and will gain importance but need to be standardized according to industrial specifications. Promising candidates for such future bio-based starting materials are $\mathrm{CO}$, methane, and methanol. Alternatively, methane and methanol are available from technical carbon recycling fueled by surplus renewable energy. This article discusses how to sustainably implement the bioeconomy in a densely populated and industrialized country by the example of Germany.
\end{abstract}

Keywords: Bio-based chemicals; Biobased residuals; Bioeconomy; Bio-fuel; Biomass; $\mathrm{CO}_{2}$; Feedstock-efficiency; Metropolitan region; Renewable energy; Synthesis gas

*Corresponding author: Manfred Kircher, Advisory Board KADIB, Frankfurt and Advisory Board CLIB2021, Düsseldorf, Germany, Tel: +49 069 95104772; E-mail: kircher@kadib.de

Citation: Kircher M (2018) Implementing the Bioeconomy in a densely Populated and Industrialized Country. Adv Ind Biotechnol 1: 003.

Received: April 13, 2018; Accepted: May 11, 2018; Published: May 25, 2018

Copyright: @ 2018 Kircher M. This is an open-access article distributed under the terms of the Creative Commons Attribution License, which permits unrestricted use, distribution, and reproduction in any medium, provided the original author and source are credited.

\section{Introduction}

The signatory states to the Paris Agreement on Climate Change have agreed to limit the accumulated emission of $\mathrm{CO}_{2}$-equivalents from fossil resources to $1000 \mathrm{Gt}$ by 2050 . This measure is expected to keep the unavoidable global rise in temperature to below $2^{\circ} \mathrm{C}$. It is therefore urgent to reduce Greenhouse Gas (GHG) emissions by going over to bio-based carbon sources and creating carbon sinks.

Alternative energy and carbon sources are going to be delivered by agri- and aquaculture as well as by forestry. However, planetary boundaries limit biomass capacities which are primarily needed to serve human nutrition. Using biomass for industrial purposes is secondary and therefore there is a demand priority setting. In addition, biomass production causes a significant ecological burden especially regarding GHG emissions. Therefore, sustainability cannot be taken for granted in the bioeconomy.

This article discusses the boundary conditions in biomass production and industrial use and explores options to reduce the footprint by improving feedstock efficiency, expanding the feedstock portfolio, and integrating renewable power systems. Germany, ranking number four in chemical industries, serves as a model example for a densely populated and industrialized country.

\section{Discussion}

\section{Taking advantage of the natural carbon cycle}

Photosynthesis generates annually 150-170 billion tons of biomass by fixing atmospheric $\mathrm{CO}_{2}[1,2]$. When biomass degrades naturally, is incinerated to generate energy, used as automotive fuel, or is disposed in the form of a biomass-derived product, the initial biomass carbon returns as $\mathrm{CO}_{2}$ into the atmosphere and enters the natural photosynthetic carbon cycle again. Theoretically, the carbon cycle of generating biomass and consuming products derived from it is balanced.

Plant biomass is therefore considered to be the sustainable alternative to fossil carbon sources (coal, natural gas, mineral oil). Currently agricultural crop biomass (carbohydrate, protein, vegetable oil, lignocellulose) in particular is used for industrial purposes but wood (lignocellulose) and algae biomass (carbohydrate, protein, vegetable oil) are going to play an increasing role.

\section{Producing biomass comes with a footprint}

However, agri- and aquaculture, and forestry need more than just sunlight. Cultivating soil, harvesting, and transporting biomass requires fuel and power. Currently the required energy is mostly fossil-based, thus contributing to the increase in atmospheric $\mathrm{CO}_{2}$. Land itself is a source of $\mathrm{CO}_{2}$ as it is emitted by the soil's microflora. When soil is cultivated by tilling and fertilizing the microflora is activated, and emission of $\mathrm{CO}_{2}$ increases. $\mathrm{N}_{2} \mathrm{O}$ is another agricultural $\mathrm{GHG}$ as microbial degradation of nitrogen fertilizer produces $\mathrm{N}_{2} \mathrm{O}$. Rice paddies emit methane when flooded because of microbial methanogenesis. 
Figure 1 shows soil- and cultivation-related GHG emission using sugar production as an example [3]. Emission is crop-specific because of differing field work and fertilizer use.

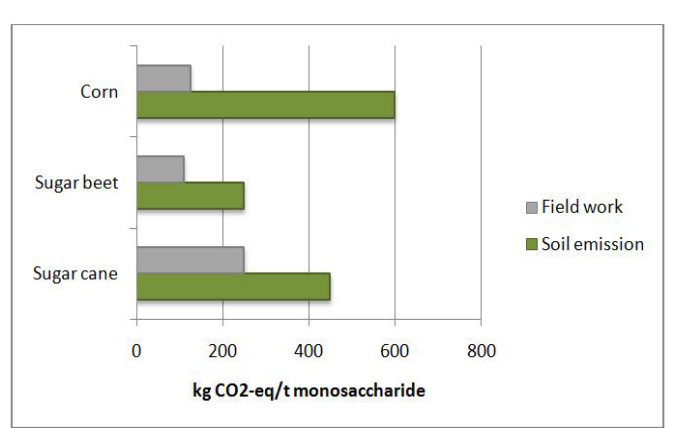

Figure 1: GHG from soil emission and field work for sugar from cane, corn and beet.

When producing ethanol from sugar cane (including cane processing and fermentation) over $90 \%$ of the total GHG emission comes from crop cultivation [4]. Taken together an estimated $22-24 \%$ of total global GHG emissions come from crop land, pasture, forests and land use changes (Figure 2) [5,6].

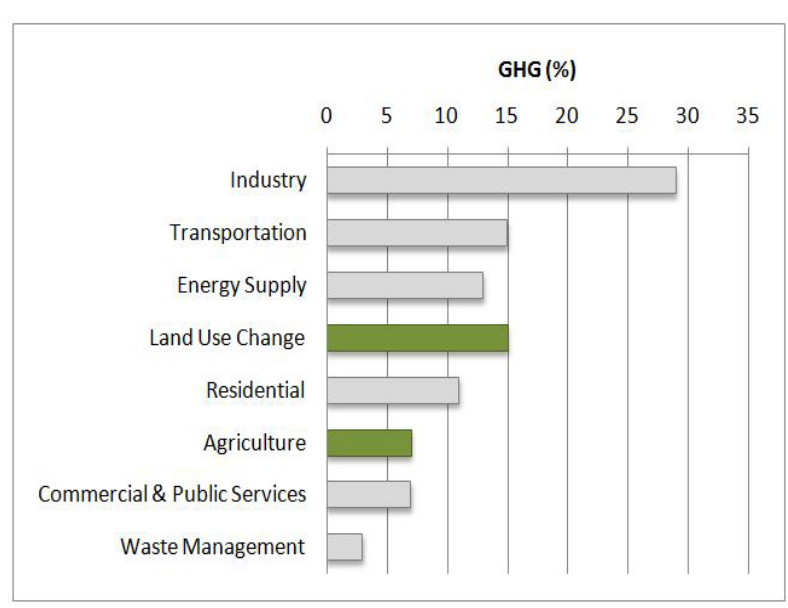

Figure 2: Global anthropogenic Greenhouse Gas (GHG) sources.

Biomass-related emissions may even grow when more bio-feedstock is demanded for industrial purposes, basic food for the growing world population, and feed and fish supply for more prosperous societies. Cattle breeding, especially ruminants, comes with significant GHG emissions not only through feed production but also by animal metabolism. Ruminants emit an estimated volume of 100 million tons of methane, which is comparable to the global leakage of natural gas (up to $3 \%$ of global natural gas production of 2.8 billion tons in 2016 $[7,8])$.

Figure 3 shows global GHG emissions related to agriculture and land use change [5]. Over a time-span of 100 years methane damages the climate 28 times and $\mathrm{N}_{2} \mathrm{O} 265$ times more than $\mathrm{CO}_{2}$.

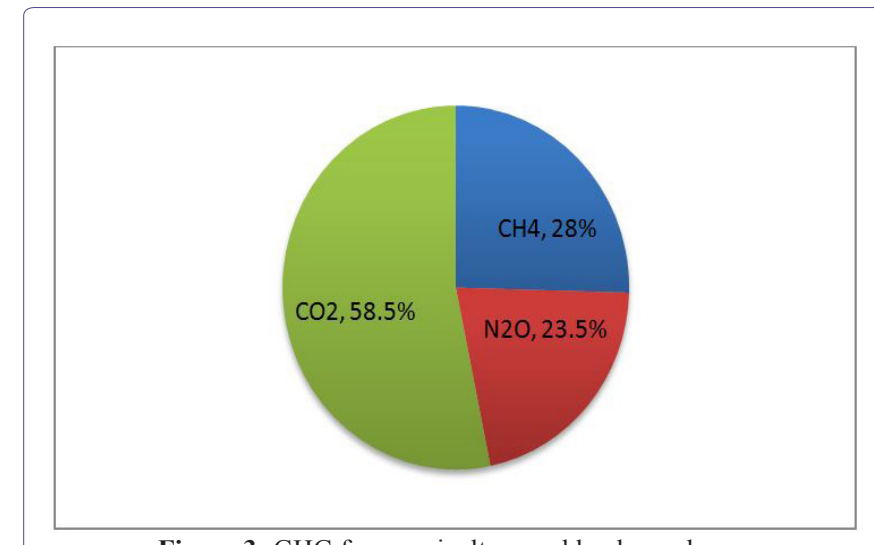

Figure 3: GHG from agriculture and land use change.

\section{Fertile land is limited}

With growing markets for food, feed and increasingly for biofuel, biopower and bio-based chemicals the demand for productive land continues to grow. However, in contrast soil is lost by erosion, salinization and contamination. Every year this affects 5-10 million hectares, an area comparable to the size of Austria. Globally an estimated $20-25 \%$ of productive land is already more or less degraded [9]. In addition, degraded land releases carbon previously stored in the soil (500 million tons/year; 2000-2009 [10]). According to a study of planetary boundaries, land productivity is already at increased risk, but biodiversity and the natural cycle of nitrogen and phosphate are currently designated high risk [11]. Phosphate, because it is a limited natural resource with only one big deposit in Morocco, and both phosphate and nitrogen because their extensive use as fertilizer leads to eutrophication [12].

A tremendous loss of biodiversity; which has declined by $58 \%$ since 1970, has been documented by the Global Living Planet Index [13]. Meanwhile there are noticeable effects on ecosystems services when, for instance, pollinating insects are missing in some areas (e.g., China [14]). The reason is not clear, but widespread monocultures and extensive use of fertilizers, herbicides and insecticides are suspected of interfering with the ecological system.

GHG footprint, land degradation, decreasing resources and effects on ecosystem services, remind us on the one hand not to overload land and natural resources and on the other to explore a more sustainable biomass production.

\section{Biotechnology and sustainable biomass production}

Improving plant yield, more sustainable fertilizers and pesticides, recycling plant nutrients and providing alternative production methods are all areas of biotechnology.

Vegetative propagation of high performance crops by meristem cultivation is state-of-the-art with potato, sugarcane, oil-palms, and more crops. This technology not only provides seedlings cost-efficiently but also accelerates the testing of new varieties.

Modern plant breeding uses technologies such as CRISPR-Cas9 to introduce input- and output-traits into the genome [15]. Input-traits 
are, for instance, drought tolerance or resistance to herbicides and insects. Resistance to glyphosate is a textbook example. This herbicide inhibits an enzyme in the biosynthesis of aromatic amino acids which is specific to plants and some bacteria. Introducing a glyphosate resistant enzyme in a crop creates a variety resistant to glyphosate. This is the prerequisite to killing weeds by broad herbicides like glyphosate and, at least equally importantly, saving tilling, thus lowering land-related emissions. Insect-resistant plants are generated by introducing the gene for insecticidal Bt-toxin from Bacillus thuringiensis.

Output-traits are, for example, crop productivity and quality. By introducing the biosynthesis pathway to $B$-carotin in golden rice its nutritional value has been improved. At Clara Foods (USA), the production of a protein identical to egg-white protein in plants is under development. If successful, this crop protein would not only be of high nutritional value (the amino acid profile of egg-white corresponds to human dietary needs) but could reduce the demand for chicken farming.

Biotechnology can help to reduce fertilizer demand by improving plant nitrogen and phosphate uptake [16]. Plant growth promoting Rhizobacteria fix atmospheric nitrogen and live in symbiosis with leguminous plants. Legumes are therefore important in crop rotation; about 120 million tons of nitrogen are fixed annually by this plant-microbial synergy [17]. The transfer of this model to more crops is under investigation [18]. Similarly, mycobacteria and mycorrhizal fungi play a symbiotic role in supporting phosphate uptake by solubilizing phosphate $[19,20]$. Better use of the soil microbiome reduces fertilizer requirements and the ecological footprint of crop production.

Producing agro chemistry more sustainably is a biotechnological topic as well. The Bt-toxin mentioned above is produced by the fermentation of Bacillus thuringiensis [21]. Nitrogen fertilizer is provided by chemical catalysis from atmospheric nitrogen and methane. Currently methane comes with fossil natural gas but could be replaced by biogas. Phosphate is a limited resource as has been mentioned earlier. Plants store phosphate in the form of phytate and, based on the phytate degrading enzyme phytase, a process has been developed to recycle phosphate from oil mill residues (Figure 4) [22]. Sewage is another source for recycling phosphate and German waste water treatment plants are obliged to recover phosphate from sludge by 2029 [23].

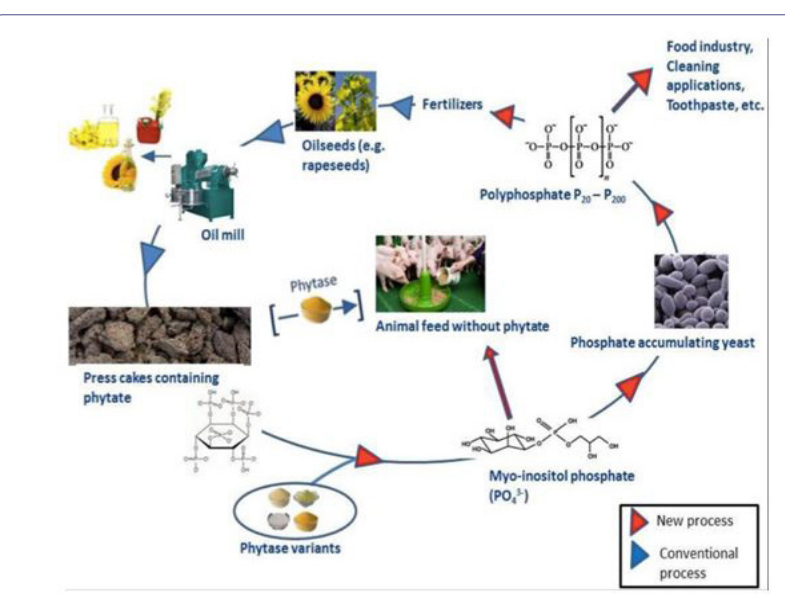

Figure 4: Process recovering phosphate from oil mill press cakes.
As animals cannot degrade phytate, phytase finds another application in degrading phytate in feed, thus reducing phosphate supplementation in animal breeding. Essential amino acids produced by microbial fermentation (esp. L-Lys, L-Thr, L-Trp) and chemical synthesis (DL-Met) are added to feed and allow the feeding of less protein. Both measures not only save phosphate and biomass resources (e.g., soy protein, fish meal) but also help to lower the phosphate and nitrogen load of manure.

Enzyme and amino acid supplementation of feed are effective examples of how to improve feed efficiency, but $71 \%$ of cropland is still used for feed production [24]. In view of future farmland demand for industrial purposes there is a real need for land-saving meat production methods.

Fish aquaculture is an option. At KnipBio (USA) microbial fish feed based on the carbon source methanol is under development; this process does not need any agricultural feedstock. The same holds true for cultivating insects at Agriprotein (USA) on plant residues from farming and food processing as a source for animal protein. Another approach to animal protein is tissue culture at Impossible Food (USA), providing animal protein without animal husbandry.

Science-based plant breeding, more sustainable agrochemistry, better use of the interaction between plants and soil microflora, alternative approaches to food protein and, last but not least, more sustainable fuel and power in farming and processing can significantly reduce land use and GHG emissions related to biomass production.

\section{Limited biomass asks for priority setting}

Many studies calculate that there is enough productive land available to supply biomass for food, feed, and fuel, chemistry, and some energy $[25,26]$. Figure 5 shows the German situation as an example of an industrialized country [27].

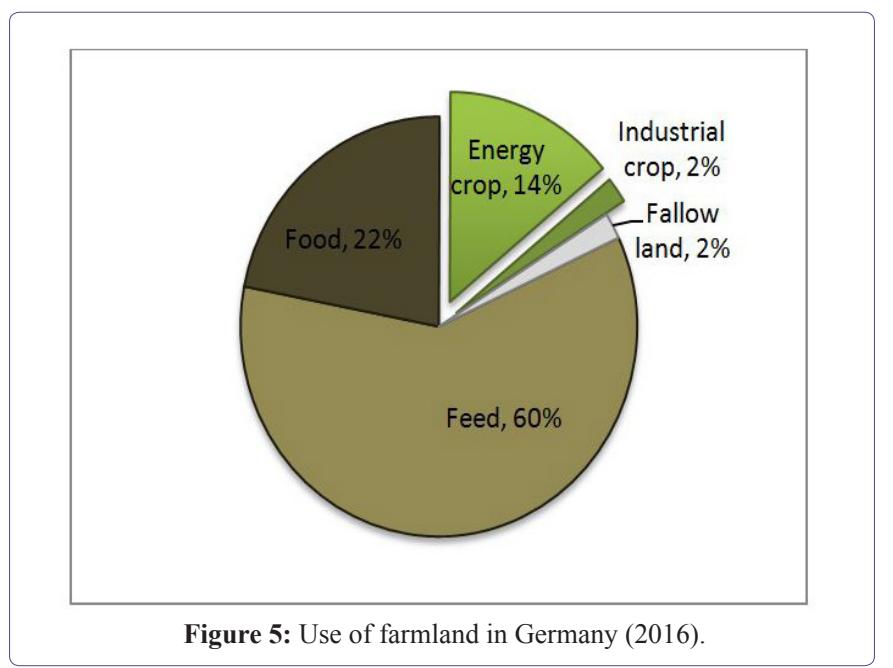

13.7 million hectares $(82 \%)$ of German farmland produce food and feed. On 2.7 million hectares (16\%) industrial crops are cultivated (Figure 5). On this land biofuel takes the major share with 59\% (65\% biodiesel, $28 \%$ bioethanol, $7 \%$ hydrogenated vegetable oil [28]). Heat and power use $28 \%$ of land to produce mainly corn to feed 
most of the 9,300 German biogas plants [29]. Chemical industries producing bio-based organic chemicals, detergents, polymers, lubricants, and pharmaceuticals demand $13 \%$ of the land (Figure 6). The required bio-based feedstock portfolio is shown in Figure 7 [27].

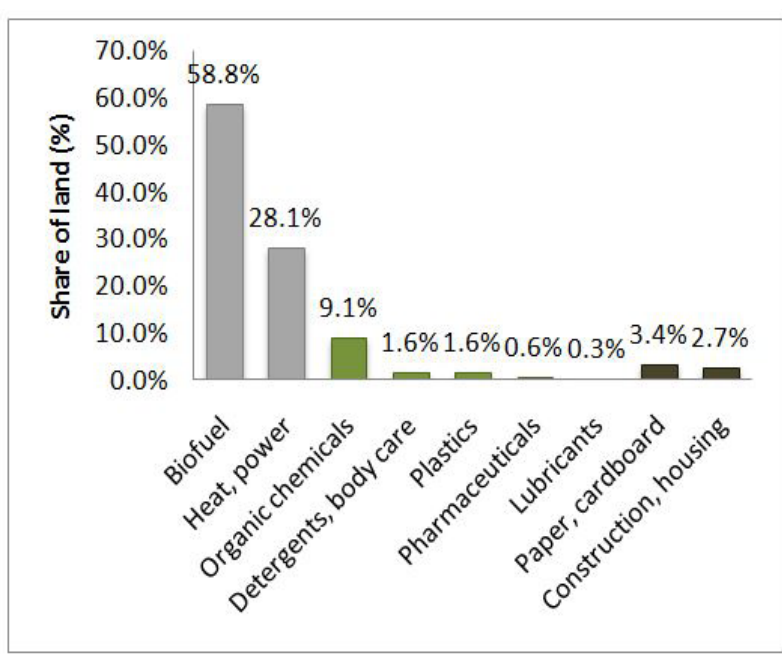

Figure 6: Share of land used for industrial purposes (Germany, 2016).

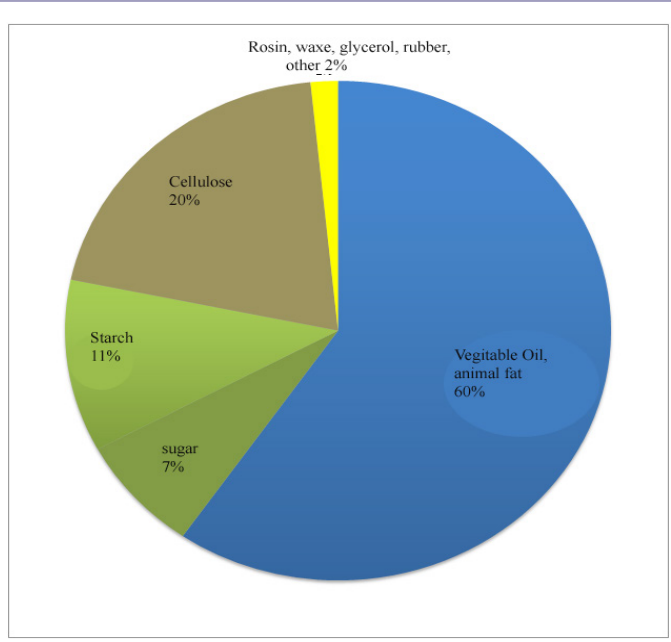

Figure 7: Bio-based raw materials in chemical industries (Germany; 2013).

An important feedstock is vegetable oil (Figure 7) coming from domestic and foreign sources [30]. For instance, lauric acid is the starting material for emulsifiers and surfactants and has a future potential in the field of bio-based polymers [31]. This saturated fatty acid with a 12 carbon atom chain is not synthesized by Western European oil crops but by tropical oil palms and is therefore imported. In other fields biomass (e.g., soy beans) or fractionated bioproducts (vegetable oil, sugar, starch) are imported to match the demand from domestic production. Domestic and imported biomass combined demand 4.37 million hectares of farmland; $62 \%$ in Germany and 38\% from abroad. In chemical production, processes depend mainly on imported biomass because of the specific composition of tropical crops, but regarding biofuel, heat and power some biomass-feedstock is imported, because the demand is too big to be matched by domestic farmland (Figure 8) [32].

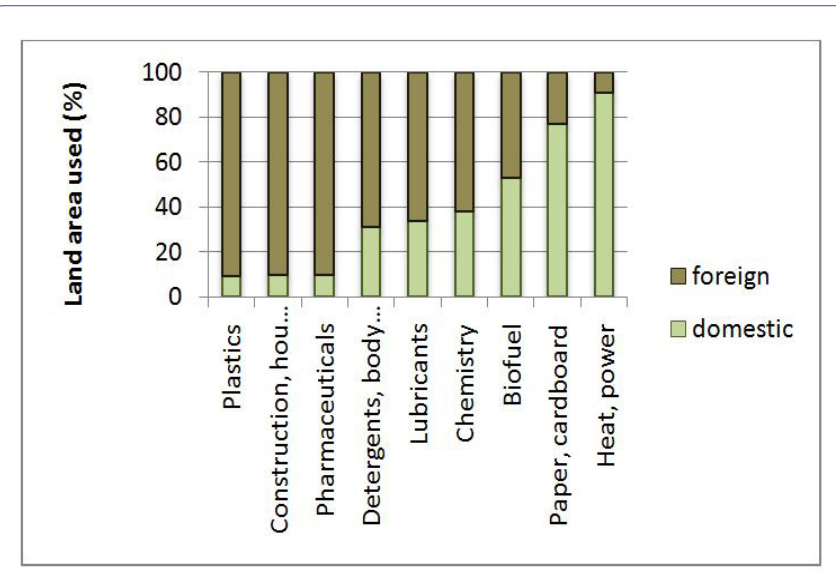

Figure 8: Share of domestic and foreign land for supplying biomass by sector (Germany; 2016).

Thus, today land is already used on a large scale for German industries. Even so, currently only $4.7 \%$ of automotive fuel and $13 \%$ of chemical feedstocks are bio-based $[33,34]$. With the bioeconomy unfolding, the demand for land for industrial biomass can be calculated to grow by factor of 10-20; or even more when including bio-energy.

However, as discussed earlier, ecosystems need room to recover and therefore land saving should be ranked as a priority. In other words, not every hectare of land recorded statistically should be considered for industrial purposes. Therefore, bioeconomy strategies need to define and select target areas for biomass use.

For example, supplying heat and power for industrial, commercial and housing purposes does not fully depend on carbon-containing feedstock because carbon-free energy is basically available from solar, wind, hydro, geothermal and nuclear power generation. Also, automotive mobility is feasible without carbon-based fuel; hydrogen and electrical power are alternatives. Only nutrition, ranked priority one, and organic chemistry depend completely on carbon sources. Some high energy density fuel for heavy-duty traffic, ships and aviation cannot be replaced in the foreseeable future and needs to be supplied as well. Focusing biomass on these sectors will help us to go easy on land and biomass resources.

\section{Improving feedstock efficiency}

Improving feedstock efficiency by the comprehensive use of all biomass components, by cascade use and carbon recycling will further help to make the bioeconomy sustainable. For instance, farmland used to cultivate rapeseed produces not only biodiesel. The press cake left over after oil milling is a valuable protein feed and glycerol results as a side product from esterifying the vegetable oil to biodiesel (Table 1). 


\begin{tabular}{|c|c|c|c|}
\hline Input & \multicolumn{3}{|c|}{ Output } \\
\hline Rapeseed & Biodiesel & Feed & Glycerol \\
\hline $3.5 \mathrm{t}$ & 1,5001 & $2 \mathrm{t}$ & $130 \mathrm{~kg}$ \\
\hline
\end{tabular}

Table 1: Product input and output in biodiesel production from rapeseed oil [35].

Exploiting biomass consistently has a tremendous impact on land demand. If considering i) flours and groats from oil milling to be used as feed, ii) fertilizer, biogas, DDGS (Dried Distillers Grains with Solubles) from side streams in processing starch and sugar crop and iii) the heat value of other residuals the German demand for crop land for industrial purposes can be reduced in theory by $33 \%$ from 4.67 to 2.9 million hectares [33].

More savings are conceivable when including more non-food biomass (lignocellulose), liquid and solid municipal and industrial waste and carbon emissions from technical processing into the feedstock portfolio. Lignocellulose consists of lignin (20-30\%), C6-sugar (60$70 \%$ ) and C5-sugar (10-20\%). Using it as a chemical feedstock needs physico-chemical preprocessing to make this extremely rigid material accessible for the enzymatic release of C5- and C6-sugar. C6-sugar is easily transformed by fermentation, but to metabolize C5-sugar industrial fermentation species such as E. coli and yeast are not naturally available. It needs genetic engineering to create appropriate biocatalysts. In fact, lignocellulosic ethanol has already entered the market and Energochemica (Slovakia) announced in 2017 lignocellulosic ethylene (sugar-based bio-ethylene has already been commercialized by Braskem (Brazil) since 2010 [36]). Using lignin as a starting material for biotechnological transformation into aromatics has also great potential but is still in an early phase [37]. In Germany the annual growth of wood is about 120 million $\mathrm{m}^{3}$ of which 106 million $\mathrm{m}^{3}$ are harvested (2007-2012 average) [38]. 14 million $\mathrm{m}^{3}$ (about 8 million tons dry mass) could be sustainably valorized as industrial feedstock presenting a volume of 5.6 million tons of lignocellulosic sugar $(70 \%$ C5-, C6-sugar; 30\% lignin). Compared to conventional sugar production by sugar beet, in theory 415,000 ha could be saved (C6-sugar yield 13.5 ton/ha). Note that putting lignocellulose and more carbon sources (see below) on the same level of utilization as C6-sugar is a rather simplified approach; however, it should give an idea about the carbon potential in these materials.

Especially in densely populated and industrialized countries great volumes of organic municipal (MSW) and industrial (ISW) solid waste streams provide another potential resource. In Germany the organic fraction of MSW is about 11 million tons containing an estimated volume of 5 million tons carbon. Translated into sugar carbon this volume corresponds to 815,000 ha sugar beet farmland [39].

Because they are highly diverse, such materials cannot be easily used as a uniform and specific industrial feedstock. By gasification, MSW can be downgraded to synthesis gas (mainly CO), thus standardizing the material. Fischer-Tropsch catalysis is an established method of transforming synthesis gas to chemicals but is economical only at a large scale. When it comes to smaller plants, for example processing a city's MSW, gas fermentation is an alternative. For example, Chlostridia transforms CO into ethanol, and, in fact, in Japan investment has been made in a MSW-based ethanol pilot fermentation plant [40]. Another advantage of microbial transformation is its specificity and therefore routes to more chemicals from $\mathrm{CO}$ are under investigation [41]. Especially in the current transition phase into the bioeconomy, when bio- and fossil carbon sources are used in parallel, CO-based gas fermentation can gain importance in all sectors providing synthesis gas. For example, steel mills generate huge volumes of synthesis gas from coal. Lanzatech, one of the pioneers in gas fermentation, is the technology provider for a pilot plant to produce ethanol from CO on an ArcelorMittal steel mill site in Ghent (Belgium) [42]. An average steel mill uses about 4 million tons of synthesis gas containing as much carbon as 0.3 million tons sugar. Produced from sugar beet, this would cover 24,000 ha. Although fossil-based synthesis gas needs to be phased out by 2050 , such projects make sense because the learning curve in gas fermentation is accelerated and biotechnological processes are implemented in an industrial sector so far unfamiliar with this discipline.

Another gaseous carbon source is $\mathrm{CO}_{2}$, especially if it comes in gas streams of high $\mathrm{CO}_{2}$ concentration. Off-gas from aerobic and anaerobic fermentation generates a feasible $\mathrm{CO}_{2}$-stream and, just like the CO-example mentioned earlier, in principle fossil $\mathrm{CO}_{2}$-sources are also suitable. Hydrogenotrophic bacteria can methanize $\mathrm{CO}_{2}$ with an efficiency of $98 \%$ when co-feeding hydrogen. If using biogas (methane, $\mathrm{CO}_{2}$ ) as the $\mathrm{CO}_{2}$-source, $\mathrm{CO}_{2}$-emission is reduced from 25$45 \%$ by volume down to less than $10 \%$ and methane yield increases from $45-75 \%$ to more than $90 \%$ [43]. Today methane is used as an energy carrier but in the future, it can provide a fuel and a carbon source for chemicals. For instance, biotechnological PHA production based on methane is already established [44]. Beside bio- also chemical catalysis is going to be used to valorize $\mathrm{CO}_{2}$. For instance Covestro works on a method to produce polyoles (especially polyoxymethylen) from $\mathrm{CO}_{2}$ and ThyssenKrupp targets on large-scale transformation of $\mathrm{CO}_{2}$ from metallurgical gas into ammonia and methanol. Turning $\mathrm{CO}_{2}$ from a liability into a feedstock is a highly attractive opportunity in a country of high carbon emission and likewise big feedstock demand. For the sake of completeness CCS (Carbon Dioxide Capture and Storage) should be mentioned as well as a tool to fight increasing levels of atmospheric $\mathrm{CO}_{2}$. This method stores $\mathrm{CO}_{2}$ geologically. $\mathrm{CCS}$ has been discussed in Germany but due to poor public acceptance this approach has not been realized until now. All technologies mentioned demand an infrastructure to transport $\mathrm{CO}_{2}$. According to a recent study a $\mathrm{CO}_{2}$ sequestration infrastructure to connect a network of biorefineries with a central conversion site within a radius of 50 miles would be feasible at $30 \mathrm{USD} /$ ton $\mathrm{CO}_{2}$ [45].

Using $\mathrm{CO}$ and $\mathrm{CO}_{2}$ can give the bioeconomy a disruptive push towards sustainability as carbon is kept in a technical cycle. Today in Germany 1,45 million ha are used to grow corn for biogas production. As about half of the biomass feedstock ends up in $\mathrm{CO}_{2}$, significant amounts of farmland could be saved if this carbon emission were utilized.

In summary, using so-called first-generation biomass (sugar, vegetable oil), second generation lignocellulose, third generation processing residuals and waste and fourth generation carbon gas expands the feedstock portfolio and improves feedstock efficiency significantly, thus saving land and reducing land-related emissions.

\section{Implementing the bioeconomy}

Methods of producing and transforming primary bio-based feedstock are available, with biotechnology providing key processes. 
However, expanding the feedstock portfolio and implementing the resulting processing and value chains is a real challenge. Feedstock needs to be standardized, processing chains should be integrated into the established industrial infrastructure, future renewable energies should be taken into account and last but not least cost hurdles need to be overcome.

Fossil carbon sources are characterized by continuous availability and high uniformity concerning composition, carbon, and energy content. In contrast, biomass and particularly the various streams of residuals and waste materials described earlier come with high volatility concerning volume, availability and quality. Such materials are difficult to match to the industrial quality requirements for reliable feedstock supply. Standardization of the diverse material streams is therefore required to convert waste and side streams into a specified industrial feedstock. Gasification to $\mathrm{CO}$ and production of methane by biogas fermentation are proven methods. Options to transform $\mathrm{CO}$ have been discussed earlier and methane in the form of natural gas is already today an important starting material in organic synthesis. By upgrading to methanol, the chemical use of methane could be expanded significantly. This alcohol contributes to feedstock supply in many sectors of organic chemistry making a market volume of about 80 million tons (2017) and in the future it may enter even more chemical routes $[46,47]$. Today it is generated from natural gas, hence starting instead from bio-methane is not a technical problem. Transporting $\mathrm{CO}$, natural gas and methanol in pipelines is state-of-the-art. Fitting into the existing logistics infrastructure is therefore another advantage of bio-based $\mathrm{CO}$, methane, and methanol.

When considering the future role of methane, the future development of renewable energies should also be taken into account. Volatile energies such as solar and wind power will play a significant role in the energy mix. Providing today $62 \%$ of renewable power (Germany, 2016) both sources produce at times significant power peaks [48]. By 2040 surplus power is expected to increase to approximately $20 \mathrm{TWh}$ (Germany) asking for its rational use [49].

Generating hydrogen by electrolysis (power-to-gas) is an option. However, because of its low volumetric density it is costly to store and transport. Furthermore, reacting hydrogen with $\mathrm{CO}_{2}$ to form methane and subsequently methanol would result in an easier to handle carbon and energy source fitting into chemical production routes. Using surplus power in this way could produce 1-2 million tons methanol per year in 2030 in Germany alone, at production cost in the range of 400-600 \$/ton [50].

Compared to a market price of $380 \mathrm{EUR} /$ ton methanol (2017, Europe) this cost level is not really competitive [51]. However, as biomass is costlier than fossil resources the bioeconomy is expected in general to have a higher cost level. When looking back the cost level in the fossil-based economy has increased as well. Adjusted to purchase power parity in 2015 the oil price in 1995 was $26 \mathrm{USD} /$ barrel and increased to $117 \mathrm{USD} /$ barrel in 2015. Nevertheless, economies adapted to the cost structure with time. Higher costs of renewable energies and feed stocks will challenge industries in a similar way but as in the past economies will have to adjust.

\section{Conclusion}

Climate change urgently demands changing the feedstock base from fossil to renewable bio-based resources. Primary biomass produced by agriculture is widely seen as the future industrial raw material. However, when considering planetary boundaries and land-related GHG emissions, the limits of land and biomass become obvious. Use of bio-carbon should therefore prioritize sectors dependent on carbon, especially organic chemistry and some fuel. Improving feedstock efficiency and expanding the feedstock portfolio to residuals, waste and gaseous carbon can contribute to efficient and sustainable production as well. These material streams are diverse and need standardization to match industrial requirements and specifications. Transformation into bio-based synthesis gas, methane, and methanol is an option to provide suitable industrial carbon and energy sources which in addition fit into the established chemical industries infrastructure.

With the bioeconomy progressing the energy sector also changes. Already today surplus renewable energies can generate hydrogen to methanize $\mathrm{CO}_{2}$ emitted from bio-based processes. The resulting methane may be further upgraded to methanol. Methane and methanol respectively provide a gaseous and liquid power storage option and a carbon source for chemical synthesis. By integrating bio-based chemical production and renewable energies, feedstock efficiency can be increased significantly while reducing GHG emissions and the demand for primary biomass, saving land. German chemical industries perform intensive research in the field of utilization of carbon gases [52]. Nevertheless Germany is expected not to meet the 2030 climate goal of reducing emission by $14 \%$ compared to 2005 . The reason for this lies mainly in using lignite-fired power stations in base load supply and balancing fluctuating renewable power sources.

It goes without saying that the domestic material streams in a single country need to be integrated into cross-border and cross-sectorial interrelationships. It is quite obvious that the German state of North Rhine-Westphalia cooperates in the BIG-Cluster initiative with Flanders (Belgium) and the Netherlands, as these countries share a similar feedstock base, population density and industrial structure [53]. BIG-Cluster focuses on using cellulosic, waste and emission carbon streams as a basic feedstock. Expanding such value chains beyond Europe needs a coordinated approach as well. For example, agreeing about the preferred use of waste materials and defining specifications for standardization would help, firstly, to make the corresponding materials a tradable feedstock commodity and secondly, to implement the bioeconomy on global scale. Not only industrialized countries will benefit. As renewable energies will gain relevance emerging economies providing such energies will also profit and attract energy-intensive processing. A suitable platform to coordinate and accelerate this transformation is the OECD (Organisation for Economic Co-operation and Development) covering 35 advanced as well as emerging countries in Europe, the Americas and Asia-Pacific. In fact, the OECD has published a bioeconomy policy agenda towards 2030 [54]. Another forum to coordinate approaches to an international bioeconomy is the Global Bioeconomy Summit hosted by the German government in Berlin (April 19 $9^{\text {th }}-20^{\text {th }}, 2018$ ). This year the conference addressed in particular Africa. The conference communiqué "calls for an increase in multilateral and cross-sectorial collaboration and coordination on bioeconomy $\mathrm{R} \& \mathrm{D}$, governance as well as in capacity building" [55]. Regionally, specific bioeconomies are unfolding worldwide; it is now important to build a truly sustainable global base from the very beginning. 


\section{References}

1. Bertau M, Offermanns H, Plass L, Schmidt F, Wernicke H-J (2014) Methanol: The Basic Chemical and Energy Feedstock of the Future: Asinger's Vision Today. Springer Science \& Business Media, Berlin, Germany.

2. Höfer R (2009) Sustainable Solutions for Modern Economies. Royal Society of Chemistry Publishing, Cambridge, UK.

3. Renouf M, Wegener MK (2007) Environmental life cycle assessment (LCA) of sugarcane production and processing in Australia. Proceedings of the Australian Society of Sugar Cane Technologists 29: 385-400.

4. Macedo IC, Seabra JEA, Silva JEAR (2008) Green house gases emissions in the production and use of ethanol from sugarcane in Brazil: The $2005 / 2006$ averages and a prediction for 2020. Biomass and Bioenergy 32: $582-595$.

5. Knapp JR, Laur GL, Vadas PA, Weiss WP, Tricarico JM (2014) Invited review: Enteric methane in dairy cattle production: quantifying the opportunities and impact of reducing emissions. J Dairy Sci 97: 3231-3261.

6. United States Environmental Protection Agency (2017) Global Green house Gas Emissions Data. United States Environmental Protection Agency, Washington, DC, USA.

7. Dave Reay (2018) Methane Sources - Ruminants. Greenhouse Gas online, Germany.

8. BP Global (2018) Natural gas production. BP Global, Grermany.

9. Boden T (2015) Internationaler Bodenschutz. Federal Environment Agency, Dessau-Roßlau, Germany.

10. The Intergovernmental Science-Policy Platform on Biodiversity and Ecosystem Services (2010) Media Release: Worsening Worldwide Land Degradation Now 'Critical', Undermining Well-Being of 3.2 Billion People. Bonn, Germany.

11. Steffen W, Richardson K, Rockström J, Cornell SE, Fetzer I, et al. (2015) Planetary boundaries: Guiding human development on a changing planet. Science 347: 1259855

12. Conley DJ, Paerl HW, Howarth RW, Boesch DF, Seitzinger SP, et al. (2009) Controlling Eutrophication: Nitrogen and Phosphorus. Science 323: $1014-1015$

13. http://awsassets.panda.org/downloads/lpr living planet report 2016 summary.pdf

14. Goulson D (2012) Decline of bees forces China's apple farmers to pollinate by hand. Chinadialogue, Beijing, Republic of China.

15. Jung C, Capistrano-Gossman G, Braaz J, Sashidhar N, Melzer S (2017) Recent developments in genome editing and applications in plant breeding. Plant Breeding 137: 1-9.

16. Gouda S, Kerry RG, Das G, Paramithiotis S, Shin H-S, et al. (2018) Revitalization of plant growth promoting rhizobacteria for sustainable development in agriculture. Microbial Research 206: 131-140.

17. Journal posts (2009) Will the research succeed in a second nitrogen revolution? Journal posts, Berlin, Germany.

18. Saber Z, Pirdahti H, Esmaeili MA, Abbasian A (2016) The effect of plan growth promoting rhizobacteria, nitrogen and phosphorus on relative agronomic efficiency of fertilizers, growth parameters and yield of wheat (Triticum aestivum L.) cultivar N-80-19 in Sari. Directory of Open Access Journals 5: 39-49.

19. Salgado FHM, Moreira FMS, Siqueira JO, Barbosa RH, Paulino HB, et al (2017) Arbuscular mycorrhizal fungi and colonization stimulant in cotton and maize. Cienc Rural 47: 6 .
20. Oufdou K, Bechtaoui N, Alaoui AE, Benidire L, Daoui K, et al. (2016) Symbiotic Rhizobacteria for Improving of the Agronomic Effectiveness of Phosphate Fertilizers. Procedia Engineering 138: 325-331.

21. Sarma SJ, Brar SK (2015) Industrial production of Bacillus thuringiensis based bio-insecticide: Which Way Forward? J Biofertil Biopestici 6: 126.

22. Schipper W, Klapwijk A, Potjer B, Lijmbach ACM, et al. (2001) Phosphate Recycling in the Phosphorus Industry. Environmental Technology 22: $1337-1345$.

23. Carraresi L, Berg S, Bröring S (2016) Emerging value chains within the bio-economy: structural changes in the case of phosphate recovery. 149th EAAE Seminar, EAAE, Rennes, France.

24. Raschka A, Carus M (2012) StofflicheNutzung von Biomasse - Basisdatenfür Deutschland, Europa und die Welt. Nova Institute $\mathrm{GmbH}$, Chemiepark Knapsack, Industriestraße, Germany.

25. Carus M (2015) Global bioeconomy in the conflict between biomass supply and demand. nova-Institut GmbH 1-4.

26. Souza G, Victoria R, Joly CA, Verdade LM (2015) Bioenergy \& Sustainability: Bridging the Gaps. Scope.

27. FNR (2017) Land use in Germany. FNR, Gülzow-Prüzen, Germany.

28. FNR (2017) Biofuel consumption Germany 2016. FNR, Gülzow-Prüzen, Germany.

29. Statista (2018) Number of biogas plants in Germany in the years 1992 to 2017. Statista, Germany

30. Rothermel J (2015) Renewable Raw Materials in the EU Chemical Industry. VCI, Frankfurt, Germany.

31. Evonik Industries (2015) Evonik Introduces Innovative Gas Separation And Contribution Towards Bio-Based Production. Evonik Industries, Essen, Germany.

32. VCI (2018) Rohstoffbasis der chemischen Industrie. VCI, Frankfurt, Germany.

33. FNR (2014) Marktanalyse Nachwachsende Rohstoffe. Fachagentur Nachwachsende Rohstoffe, Gülzow, Germany.

34. FNR (2017) Fuel consumption in Germany. FNR, Gülzow-Prüzen, Germany.

35. FNR (2018) Biodiesel. FNR, Gülzow-Prüzen, Germany.

36. Energochemica Se (2015) Biorefinery in the Eastern Slovakia. Energochemica Se, Czech Republic.

37. VITO (2017) Biomass to Aromatics. VITO, Boeretang, Belgium.

38. Bundeswaldinventur (2012) Wood use at a high level. Bundeswaldinventur, Germany.

39. Federal Statistical Office of Germany (2018) Publications in the field of waste management. Federal Statistical Office of Germany, Federal Statistical Office of Germany.

40. LanzaTech (2017) From Trash to Tank: Upcycling of Landfill to Fuel Demonstrated in Japan. LanzaTech, USA.

41. Global Bioenergies (2017) Global Bioenergies finalizes acquisition of Syngip. Global Bioenergies, France.

42. http://corporate.arcelormittal.com/news-and-media/news/2015/july/1307-2015\%20Microbenergy

43. https://www.h2fc-fair.com/hm13/exhibitors/microbenergy.html

44. http://mangomaterials.com/technology/ 
45. Sanchez DL, Johnson N, McCoy ST, Turner PA, Mach KJ (2018) Nearterm deployment of carbon capture and sequestration from biorefineries in the United States. Proc Natl Acad Sci USA 115: 4875-4880.

46. Alvarado M (2016) The changing face of the global methanol industry. London, United Kingdom.

47. Bertau M, Wernicke HJ, Schmidt F (2014) Methanol utilisation technologies. In: Bertau M, Offermanns H, Plass L, Schmidt F, Wernicke H-J (eds.). Methanol: The basic chemical and energy feedstock of the future. Springer, Berlin, Germany.

48. BMWi (2017) Renewable energies. Berlin, Germany.

49. Statista (2018) Volumen der zu speichernden Stromüberschüsse* in Deutschland in den Jahren 2025 und 2040 (in Terawattstunden). Hamburg, Germany.

50. Plass L, Bertau M, Linicus M, Heyde R, Weingart E (2014) Methanol as a hydrogen and energy carrier. In: Bertau M, Offermanns H, Plass L, Schmidt F, Wernicke H-J (eds.). Methanol: The basic chemical and energy feedstock of the future. Springer, Berlin, Germany.
51. Statista (2018) Durchschnittlicher Preis für Methanol auf dem europäischen Markt in den Jahren von 2012 bis 2018 (in Euro je Tonne). Hamburg, Germany.

52. Bazzanella A, Krämer D (2017) Technologien für Nachhaltigkeitund Klimaschutz - Chemische Prozesse und stoffliche Nutzung von $\mathrm{CO}_{2}$. Dechema, Germany.

53. BIG-C (2018) C1-Bioconversion. BioInnovation Growth mega-Cluster, Duesseldorf, Germany.

54. OECD (2009) The Bioeconomy to 2030: designing a policy agenda . OECD, Paris, France.

55. Global Bioeconomy Summit (2018) Innovation in the Global Bioeconomy for Sustainable and Inclusive Transformation and Wellbeing. Global Bioeconomy Summit, Berlin, Germany. 